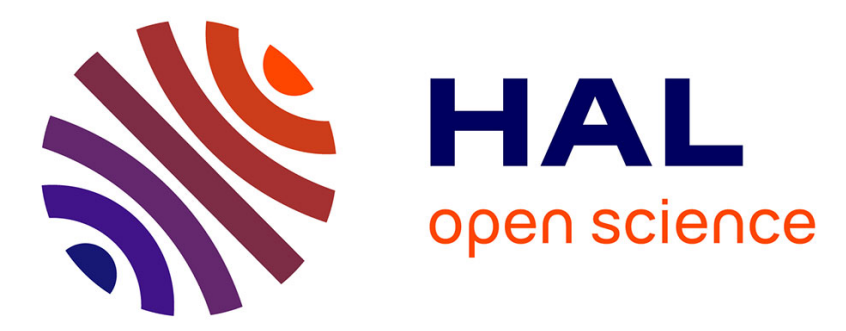

\title{
Ecology of Anthocoris nemorum (L.) (Het.: Anthocoridae) and evaluation of its potential effectiveness for biological control of pear psylla
}

Franck Herard, Kim Chen

\section{- To cite this version:}

Franck Herard, Kim Chen. Ecology of Anthocoris nemorum (L.) (Het. : Anthocoridae) and evaluation of its potential effectiveness for biological control of pear psylla. Agronomie, 1985, 5 (10), pp.855-863. hal-00884713

\section{HAL Id: hal-00884713 https://hal.science/hal-00884713}

Submitted on 1 Jan 1985

HAL is a multi-disciplinary open access archive for the deposit and dissemination of scientific research documents, whether they are published or not. The documents may come from teaching and research institutions in France or abroad, or from public or private research centers.
L'archive ouverte pluridisciplinaire HAL, est destinée au dépôt et à la diffusion de documents scientifiques de niveau recherche, publiés ou non, émanant des établissements d'enseignement et de recherche français ou étrangers, des laboratoires publics ou privés. 


\title{
Ecology of Anthocoris nemorum (L.) (Het. : Anthocoridae) and evaluation of its potential effectiveness for biological control of pear
} psylla

\author{
Franck HERARD \& Kim CHEN \\ European Parasite Laboratory, USDA, ARS, 13-17, rue de la Masse, Behoust, F 78910 Orgerus
}

\begin{abstract}
Ecology of Anthocoris nemorum (L.) and of pear psylla populations was studied in orchards in the Paris region. A. nemorum was abundant on pear trees only in autumn, apparently searching for hibernation sites. In summer, it preferred to stay in the herbaceous stratum, especially in nettle, where it preyed upon various species of insects, which were more favorable for its proliferation than Psylla pyri (L.). It was determined that in the Paris region, $A$. nemorum had 3 overlapping generations, and the hibernating females showed a simple slow-down of ovarian development, not a reproductive diapause. The predatory behavior of $A$. nemorum is described. Its voracity, the effect of prey density on predator voracity, and its reproductive performance were evaluated by presenting several potential prey species. The rather weak nutritive value of $P$. pyri as prey, and the poor quality of pear leaves as an egg-laying site for $A$. nemorum, indicate its low potential value in biological control of the pest.
\end{abstract}

Additional key words : Voltinism, hibernation, predatory behavior, effect of prey density, reproductive performances, egg laying sites.

RÉSUMÉ

\begin{abstract}
Ecologie d'Anthocoris nemorum (L.) (Het.: Anthocoridae) et évaluation de son efficacité potentielle comme agent de lutte biologique contre le psylle du poirier.

L'évolution des populations d'Anthocoris nemorum (L.) et du psylle du poirier est étudiée dans des vergers de la région parisienne. $A$. nemorum est abondant en automne seulement sur les poiriers où, apparemment, il recherche des abris d'hibernation. En été, il préfère se tenir dans la strate herbacée, en particulier les orties, où il attaque divers insectes plus favorables que Psylla pyri (L.) à sa prolifération. Dans la région de Paris, A. nemorum développe 3 générations chevauchantes et les femelles hivernantes présentent un simple ralentissement de leur développement ovarien et non une diapause ovarienne. Le comportement de prédation d'A. nemorum est décrit. Sa voracité, l'effet de la densité de proies sur la voracité du prédateur et ses performances reproductrices ont été évalués en présence de plusieurs espèces-proies. La valeur nutritive assez faible de $P$. pyri comme proie et la mauvaise qualité des feuilles de poirier comme site de ponte pour A. nemorum font que ce prédateur est trop peu lié au psylle du poirier pour être considéré comme un agent biologique potentiel dans la lutte contre le ravageur.
\end{abstract}

Mots clés additionnels : Voltinisme, hibernation, comportement de prédation, effet de la densité de proies, performances reproductrices, site de ponte.

\section{INTRODUCTION}

It was established (BOUYJOU et al., 1984 ; NGUYEN \& Delvare, 1984 ; Herard, 1985) that the anthocorids were among the most abundant predators in all the orchards infested with Psylla pyri (L.), in France ; one species, Anthocoris nemoralis (F.) was found in northern and southern France. Although it is a very polyphagous predator, its most common prey are psyllids (ANDERSON, 1962a). A literature review (HERARD, 1986 accepted for publication) showed that it is a permanent component of the biocomplex of the pear psylla in Europe, and the major limiting factor of the pest. A. nemoralis was introduced in 1963 in North America to be used in the control of Psylla pyricola Foerster. It was successfully established (Mc Mullen \& JONG, 1967 ; FieldS \& BEIRNE, 
1973 ; ClAUSEN, 1978) ; it has dispersed and even replaced the native predators, Anthocoris antevolens White and Anthocoris melanocerus Reuter as the most common anthocorid predator in some orchards (FIELDS \& BEIRNE, 1973).

A 2nd species of the same genus, Anthocoris nemorum (L.), was frequently observed by us on pear trees in the Paris region, where it was especially abundant in autumn. On the other hand, we never found it in southern France. Although $A$. nemorum was mentioned several times as a predator of pear psylla in Europe (BONNEMAISON \& MISSONNIER, 1956 ; GEORGALA, 1957 ; WOJNAROWSKA et al., 1960 ; BRONNIMANN, 1964 ; CARL \& ZWÖLFER, 1965 ; SCHEURER et al., 1975 ; NGUYEN et al., 1981), its degree of association with the pest is unknown. Nevertheless, it was decided to attempt introduction in the USA of $A$. nemorum, using individuals from our USDA/EPL culture. First releases were made in pear-growing areas of the Yakima Valley (Washington) where $P$. pyricola occurs.

As a complement to evaluation of the effect of $A$. nemorum in the U.S., we made the following study to ascertain the degree of association between $A$. nemorum and the pear psylla $(P$. pyri) in France. We attempted to determine if the impact of the predator on its host is commensurate with its level of presence in orchards. In the field, we followed the evolution of predator and prey populations, and discovered some characteristics of $A$. nemorum ovarian development in winter. We observed in the laboratory the predatory behavior of $A$. nemorum, evaluated its reproductive performance when fed various prey, and evaluated quality of pear leaves as its egg-laying site.

\section{MATERIALS AND METHODS}

A. nemorum larvae and adults and $P$. pyri adults were sampled from July 1982 to September 1983 in three $5,000 \mathrm{~m}^{2}$ pear orchard plots located in the truck farming plain of Carrières-sous-Poissy (Yvelines, France). Counting was made by beating 50 branches (1 branch per tree) above a $0.5 \mathrm{~m}^{2}$ tray. The fauna of the herbaceous stratum, especially nettle close to the orchards, was also collected via 200 sweeps per site at each sampling date. Occurrence of $A$. nemorum was also recorded on various trees in the natural orchard environment. Collection of hibernating $A$. nemorum adults was accomplished using artificial hibernacula traps made from corrugated cardboard plates, which were stapled on pear tree trunks just above the ground, and on stakes placed in the nettles. Dissection of $A$. nemorum females revealed fat body and ovarian development.

$A$. nemorum was reared in the laboratory at $21 \pm 1{ }^{\circ} \mathrm{C}$ and $60-70 \%$ relative humidity,

(1) on barley sprouts infested with the aphid, Metopolophium dirhodum (Walker),

(2) on pear twigs infested with $P$. pyri dipped in aerated water,

(3) on nettle feeders such as the aphid, Microlophium evansi (Theobald), the psyllid, Trioza urticae L., and the cicadellids, Eupteryx urticae (F.) and Eupteryx aurata (L.), and
(4) on eggs of Ephestia kuehniella Zeller. Other prey species, Myzus persicae (Sulzer), Schizaphis graminum (Rondani), and Brevicoryne brassicae L., were also used in food choice and voracity evaluation experiments.

\section{RESULTS}

\section{A. Development of $A$. nemorum and $P$. pyri populations}

A. nemorum was absent from pear trees in July and August 1982 because of deltamethrin (Decis) applications against pear psylla in the orchards studied (fig. 1). During the same period, it was abundant in nettle. Reduction of its population on nettle in September and October corresponds with lack of prey on this host plant. At the same time the population of $A$. nemorum increased on pear trees due to cessation of spraying one month before harvest and the resultant abundance of psylla. COLLYER (1967) also noted that $A$. nemorum was quick to adjust itself to an adequate food supply.

Not one young $A$. nemorum larva was found on pear trees after late September. Although females had been fertilized, they did not lay eggs in autumn. Matings had been observed, and dissection of females showed that sperm pouches had been filled. However, ovarioles contained only one slightly developed oocyte. These adults were then prehibernating individuals, gathered on pear trees where they fed, increased their fat body, mated and found hibernation sites.

In October and early November, $A$. nemorum adults left pear tree branches and entered their hibernation sites in bark crevices at the bottom of trees. We trapped them there in corrugated cardboard traps. The sex-ratio of individuals occurring in autumn was one to one, and among hibernating adults, 7 females for one male. Most of the males died before winter, after they had inseminated the prehibernating females. Most of the hibernating adults survived the severe winter very well.

By the end of winter, the sex-ratio ( 7 females for one male) among adults resuming their hunting activity indicated the same small proportion of males recorded in the overwintering traps. These results coroborate those obtained in England by COLLYER (1967) and ANDERSON (1962b). In Scotland, HILL (1957) noted that only very exceptionally were males found in spring.

In $1983, A$. nemorum resumed its activity the end of March in the Paris region (fig. 1), a little after the 1st oviposition by $P$. pyri, and at the moment of pear tree flowering. In using the pear tree as a habitat for overwintering, adults of $A$. nemorum were thus well situated for survival the beginning of spring. They were able to find there the eggs of psylla placed in abundance at the base of the buds, as well as other prey in the form of various small insects attracted by early flowering of the pear tree. However, their apparent level of population remained low (fig. 1), likely due to the 1 st chemical sprays with deltamethrin and movement of adults towards nettle, where their population increased regularly until the end of June. 


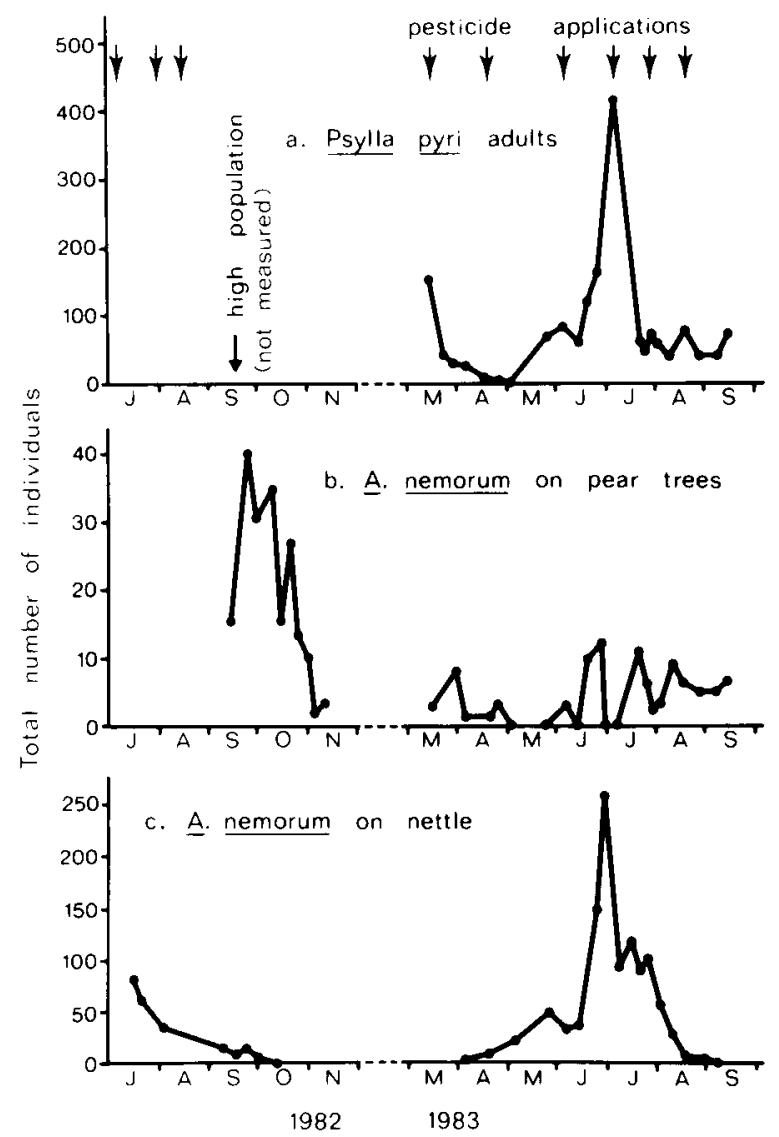

Figure 1

Populations of Anthocoris nemorum and Psylla pyri in the Paris region, 1982-1983.

a, b. obtained by beating 50 branches (I branch per tree) over a $0.5 \mathrm{~m}^{2}$ tray; c. obtained in 200 sweeps.

Populations d'Anthocoris nemorum et de Psylla pyri dans la région parisienne en 1982-1983.

a, b. obtenu par battage de 50 branches (I branche par arbre) au-dessus d'un plateau de $0,5 \mathrm{~m}^{2}$; c. obtenu en 200 coups de filet fauchoir.
The $A$. nemorum populations remaining on pear tree during the summer, suffered fluctuations partly due to the depressive effect of repeated deltamethrin applications, and partly due to the fact that $P$. pyri is simply an occasional or alternate prey for this predator.

In 1982 and 1983, A. nemorum left nettle in July (fig. 1), as the prey became rare in this habitat. Although the pear psylla population was large, $A$. nemorum adults leaving nettle did not establish on pear trees because of the action of pesticides. On the other hand, we found high numbers of $A$. nemorum in July on hazel, maple, lime, and beech trees close to the orchards. These trees were heavily infested with aphids and could serve as reservoirs for beneficial insects and probably favor new colonizations of orchards.

\section{B. Voltinism}

HILL (1957) and PARKER (1975) determined that $A$. nemorum developed only one generation per year in Scotland. In Southern England, ANDERSON (1962c) and COLLYER (1967) showed that $A$. nemorum has 2 generations per year. PARKER (1975) determined that differences in reproductive physiology of these 2 races are of a genetic nature. BONNEMAISON \& MISSONNIER (1956) presumed that $A$. nemorum has 3 generations in France. We confirmed the occurrence of 3 overlapping generations in the Paris region (fig. 2).

In 1983, adults coming out of hibernation in midMarch were found until late May. The 1st generation developed from mid-March to mid-July; the 2nd from late June to late September ; the $3 \mathrm{rd}$ from midAugust to late October (fig. 2).

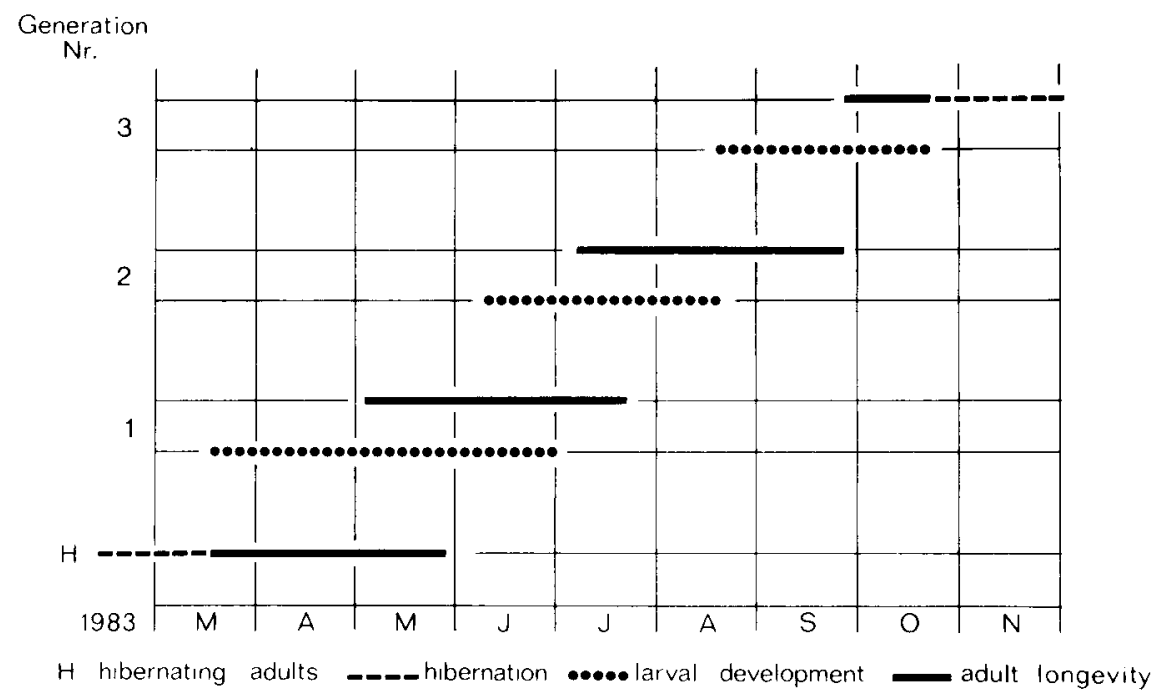

Figure 2. 


\section{Hibernation}

Concerning the halt in ovarian development during winter, HILL (1957), PARKER (1975), ANDERSON (1962c) and COLLYER (1967), observed important differences in $A$. nemorum female populations from Scotland and from southern England. They stated that reproductive diapause is obligatory in females from Scotland and optional in females from southern England. In England, females collected any time after late December readily laid eggs within a few days, while females collected before late December laid no eggs unless they were first subjected to a period of cold. According to COLLYER (1967), reproductive diapause is induced in the summer while conditions are still favorable. Diapause stops after a period of cold equivalent to November and December of the English winter; after that, oviposition is only inhibited by low temperature and lack of food.

In Germany, the biology of $A$. nemorum was studied by LAUENSTEIN $(1976,1977,1980 a, 1980 b)$. This author distinguished 2 groups of females in a population. Some $(20 \%)$ paired and oviposited during the same vegetation period in which they emerged, and $80 \%$ paired but still needed exposure to cold before they would oviposit.

Results we obtained in the Paris region were different from those of English and German authors. We collected prehibernating and hibernating fertile females in nature from October 1982 to January 1983. They were held in the laboratory at $21 \pm 1{ }^{\circ} \mathrm{C}$, in 60 $70 \%$ relative humidity, and $16 \mathrm{~h}$ photophase, and fed aphids from barley. Table 1 shows that in October 1982, about an equal proportion of prehibernating females laid and did not lay eggs. Consequently, we can conclude that there was not an obligatory diapause in this population from the Paris region. Some females laid eggs after a period of ovarian maturation of 7-35 days following the date of collection (table 1). Three generations of predators had been developed by the end of March 1983 from these eggs. Table 1 shows that in the laboratory, the pre-oviposition period was longer in the females collected 1st, probably because they had not developed fat bodies which would have been used for ovarian maturation. Conversely, overwintering females collected in December had already developed their reserves during autumn, and ovarian maturation was able to take place immediately after they were placed under laboratory conditions. Ovarian development was simply inhibited by cold, as was general activity of the insect; it resumed immediately when the insects were placed in an artifical springtime environment. No obligatory period of cold was necessary for resuming ovarian development among individuals collected in autumn. Therefore, one cannot speak of ovarian diapause in the ecological race occurring in the Paris region but rather of "ovarian slow-down" caused by winter temperatures.

Thus, adults of $A$. nemorum continue to be active in nature as temperature permit. They feed and mate, while the fat bodies of the female grow in volume and weight. Dissection of females collected at the beginning of autumn still showed, generally, a very thin fat body and very small ovarioles. At the end of autumn, fat bodies were larger, but the ovarioles were still fine. At the moment when the fat bodies were more or less developed (with very large individual variability), winter cold forced the females to seek shelter for overwintering, and it maintained them in ovarian pause.

In any case, ovarian pause was not total during winter. Females collected between October and the end of December 1982 and maintained at $4{ }^{\circ} \mathrm{C}$ during 90 days in total darkness in individual tubes embedded in plaster of Paris, were dissected March 1983. They showed a fat body of very large to medium size and oocytes in the course of maturation, and even some mature eggs (table 2). Another lot of females, hibernating under the same conditions, was placed in March 1983 at $21 \pm 1{ }^{\circ} \mathrm{C}$ and $16 \mathrm{~h}$ photoperiod and $60-70 \%$ relative humidity with cereal aphids on barley. A few of them began to lay eggs after 2 days. Therefore, there was no pre-oviposition period among these females. Their eggs had matured progressively during the course of hibernation.

PARKER (1975) observed in diapausing females from Scotland that diapause termination was a gradual process and to a certain extent related to the individual. He observed no clear relationship between

TABLE 1

Duration of preoviposition period in A. nemorum females collected in nature (I) by beating pear trees,

(2) in artificial hibernacula traps on pear trees, (3) in artificial hibernacula traps on nettle.

Durée de la période de préoviposition chez des femelles d'A. nemorum récoltées dans la nature (1) par battage des poiriers, (2) dans des pièges d'hivernation sur poiriers, (3) dans des pièges d'hivernation dans les orties.

\begin{tabular}{lcccc}
\hline \hline Date of collection & $\begin{array}{c}\text { Number } \\
\text { of females }\end{array}$ & $\begin{array}{c}\text { Number } \\
\text { of females which } \\
\text { laid eggs }\end{array}$ & $\begin{array}{c}\text { Duration of } \\
\text { preoviposition } \\
\text { period (days) }\end{array}$ & $\begin{array}{c}\text { Average } \\
\text { duration } \\
\text { (days) }\end{array}$ \\
\hline Oct. 12 to $16,1982(1)$ & 17 & 9 & 35 to 38 & 35.7 \\
\hline Oct. 25 to Nov. 15, 1982 (1) & 14 & 9 & 16 to 20 & $\mathbf{1 7}$ \\
\hline Dec. 28, $1982(2)$ & 22 & 20 & 7 to 13 & 9.5 \\
\hline Jan. 18, $1983(3)$ & 16 & 14 & 5 to 13 & 7 \\
\hline \hline
\end{tabular}


TABLE 2

Condition of fat body and development of ovarioles in pre-hibernating and hibernating A. nemorum females (1) females 1 to 11 collected by beating pear trees, (2) females 12 to 19 collected in hibernacula.

Etat du corps adipeux et niveau de développement des ovarioles chez des femelles préhivernantes et hivernantes d'A. nemorum ;

(1) femelles 1 à 11 récoltées par battage des poiriers, (2) femelles 12 à 19 récoltées dans des pièges d'hivernation.

\begin{tabular}{|c|c|c|c|c|c|}
\hline Female no. & $\begin{array}{l}\text { Date of } \\
\text { collection }\end{array}$ & $\begin{array}{l}\text { Duration of cold } \\
\text { period \& darkness }\end{array}$ & $\begin{array}{l}\text { Development } \\
\text { of ovarioles }\end{array}$ & $\begin{array}{l}\text { Condition } \\
\text { of fat body }\end{array}$ & $\begin{array}{c}\text { Condition } \\
\text { of sperm pouch }\end{array}$ \\
\hline & (1) & & & & \\
\hline 1 & $21 \times I 82$ & 159 & $2 \mathrm{~d}$ oocyte present & reduced & replete \\
\hline 2 & - & - & $2 \mathrm{~d}$ oocyte present & reduced & replete \\
\hline 3 & - & - & fully developed & very reduced & replete \\
\hline 4 & - & - & $2 \mathrm{~d}$ oocyte present & reduced & replete \\
\hline 5 & - & - & $2 \mathrm{~d}$ oocyte present & reduced & replete \\
\hline 6 & - & - & $2 \mathrm{~d}$ oocyte present & reduced & replete \\
\hline 7 & - & - & $2 \mathrm{~d}$ oocyte present & large & replete \\
\hline 8 & - & - & 3d oocyte present & reduced & replete \\
\hline 9 & $16 \times 82$ & 155 & $3 \mathrm{~d}$ oocyte present & reduced & replete \\
\hline 10 & $9 \times 182$ & 141 & $3 \mathrm{~d}$ oocyte present & reduced & replete \\
\hline \multirow[t]{2}{*}{11} & - & - & $2 \mathrm{~d}$ oocyte present & large & replete \\
\hline & (2) & & & & \\
\hline 12 & 28 XII 82 & 90 & $3 \mathrm{~d}$ oocyte present & very reduced & replete \\
\hline 13 & - & - & $3 \mathrm{~d}$ oocyte present & large & replet: \\
\hline 14 & - & - & $3 \mathrm{~d}$ oocyte present & very reduced & replete \\
\hline 15 & - & - & $2 \mathrm{~d}$ oocyte present & very reduced & replete \\
\hline 16 & - & - & $3 \mathrm{~d}$ oocyte present & reduced & replete \\
\hline 17 & - & 一 & $3 \mathrm{~d}$ oocyte present & very reduced & replete \\
\hline 18 & - & - & $2 \mathrm{~d}$ oocyte present & reduced & replete \\
\hline 19 & - & - & fully developed & very reduced & replete \\
\hline
\end{tabular}

length of cold period and state of ovariole development. He believed that state of the females before overwintering could be important, especially with regard to size of the fat body. ANDERSON (1962b) also had observed in England in diapausing females that a slight ovarian development occurred during March, though his specimens were held at $1{ }^{\circ} \mathrm{C}$ and had no access to food.

In our experiment photoperiod did not play any role in resumption of ovarian maturation, since the females were maintained for 3 to 5 months in total darkness. No particular factor exists to trigger ovarian maturation; this occurs very slowly during winter.

Metabolic rate of $A$. nemorum females from the Paris region was therefore not reduced during overwintering as one may have expected. In overwintering adults, we measured weight loss, which would indicate utilization of their reserves for metabolic needs during winter. Average weight of pre-hibernating females collected in October 1982 was about $1.71 \pm 0.13 \mathrm{mg}$. The end of winter (end of March 1983), these females weighed only $1.24 \pm 0.13 \mathrm{mg}$. Average weight loss was $0.47 \mathrm{mg}$ during 5 months, or $27 \%$ of their weight. During a similar winter period, ANDERSON (1962 $b$ ) noted a weight loss in overwintering individuals of $17 \%$ at $1{ }^{\circ} \mathrm{C}$.

Thus, metabolism seems to have been higher in non-diapausing overwintering females from the Paris region than in diapausing females from England.

Consequently, winter cold in the Paris region, at the very most, strongly slowed ovarian maturation. Females of this population neither showed ovarian diapause nor true ovarian quiescence.

\section{A. nemorum feeding behavior}

\section{Sequence of predatory behavior}

We continually observed a female $A$. nemorum during $8 \mathrm{~h}$. She had not been fed for $24 \mathrm{~h}$. This insect was placed in a $70 \mathrm{cu} . \mathrm{cm}$. plastic cage in the presence of 6 prey belonging to 6 different species, the aphids, $M$. persicae, $S$. graminum, $M$. dirhodum, $B$. brassicae, and the psyllids, T. urticae and $P$. pyri. Observation was repeated with another female $A$. nemorum, resulting in the same pattern of behavior.

The predator 1 st walked about at random in the cage. It accidentally came in contact with a prey in about $75 \mathrm{~s}$. This was a 4 th instar $P$. pyri nymph. This encounter set off the predatory reflex, a flexing of the proboscis and penetration of the stylets into the side of the thorax of the prey. The prey was very quickly lifted from the substrate, which impeded it from grasping it and attempting to escape. The prey was then paralysed by the saliva of the predator ; it ceased all movement $2 \mathrm{mn}$ after the attack. The predator emptied its prey in $36 \mathrm{mn}$. During the lapsed time, it changed the point of insertion of its stylets 9 times. Curiously, the prey was turned without the stylets being withdrawn when the predator was bothered by an aphid which bumped it. Then it stretched, carrying its prey at the extremity of its rostrum without losing it. Only $5 \mathrm{~s}$ after having lef its $1 \mathrm{st}$ prey, the pradator encountered another and immediately attacked it successfully. This 2 nd prey was a nymph of $B$. brassicae; the contents were also totally consumed. During 
the course of its meal, $A$. nemorum consumed successively 5 prey before becoming indifferent to additional encountered prey. Only the first 3 prey were totally emptied. The next 2 were only partially consumed. The encounter with a 6 th prey stimulated only a reflex reaction, an extension of the rostrum, but there was no insertion of stylets. Then there was a period of quiescence. Total duration of the meal was about $2 \mathrm{~h}$ and $30 \mathrm{mn}$. During the following $3 \mathrm{~h}$ and $30 \mathrm{mn}$, A. nemorum did not attack any other prey; it rested immobile for most of the time.

\section{Voracity}

Feeding was calculated daily in the laboratory using A. nemorum adults presented with the 6 prey species mentioned above. Fourteen pre-overwintering females, collected in nature between September 30 and October 10,1982 , were tested. Five fully grown nymphs belonging to 5 among these 6 species plus 10 individuals of the smaller $T$. urticae nymphs were presented simultaneously to one $A$. nemorum female in a $70 \mathrm{cu} . \mathrm{cm}$. plastic cage. Number of prey killed in each species was recorded after a $2 \mathrm{~h}$ period. Results are reported in table 3 .

Table 3 shows that they accepted all prey almost equally, at the rate of 2 to 3 individuals of each species. The number of nymphs of $T$. urticae consumed was the greatest among the proffered species, probably because they were more numerous and because of the predatory behavior of $A$. nemorum. When we placed the predator 1 st in the cage, followed by the different successive prey, the prey 1 st attacked was that presented 1 st. When we placed several prey in the cage and the predator last, the 1st prey attacked was that encountered 1st. The higher number of nymphs of $T$. urticae consumed must have been due to the probability of its having been encountered more often, since they were more numerous at the beginning. The pre-overwintering females of $A$. nemorum, therefore, consumed about 19 prey per day, without showing any particular preference for any one species among the 6 species presented.

\section{Effect of prey density on predator voracity}

Two prey, $P$. pyri and $M$. persicae, were tested. Each was presented during $24 \mathrm{~h}$, at densities of 10 , 30 , and 60 individuals per cage (measuring $70 \mathrm{cu} . \mathrm{cm}$.) to a pre-overwintering female of $A$. nemorum. Fifteen $A$. nemorum females were tested with $P$. pyri and 18 females with $M$. persicae. Average values of voracity are presented for the 2 species at each density in table 4.

Voracity of $A$. nemorum doubled when number of nymphs of $M$. persicae ranged from 10 to 30 , but it did not increase any more if the number went from 30 to 60 . In the presence of $P$. pyri, $A$. nemorum showed the same voracity no matter what the density of prey. If we compare voracity of $A$. nemorum on $M$. persicae and on $P$. pyri at equal densities, we see that a density of 10 induced equal attack on the 2 species of prey. However, at densities of 30 and 60 , the number of $M$. persicae consumed was significantly higher than P. pyri.

If we compare tables 3 and 4 , we can see, for density 30-35 that the predator did not show the same daily voracity for various species of prey (19 prey attacked) (table 3), as compared with the situation where a single species was presented (14 prey attacked when $M$. persicae was presented ; and 6 , when it was $P$. pyri) (table 4). If $A$. nemorum's preference for varied prey is confirmed, there is little chance of its being very efficient in a habitat such a pear orchard infested mainly with pear psylla.

\section{E. Reproductive performance of $A$. nemorum}

Colonization of a habitat by a predator depends namely on its rate of proliferation, itself depending on the nutritive value of the prey. Thus, we compared in the laboratory the nutritive value of several prey by measuring reproductive performance of the predator fed on these prey.

Reproductive performance was evaluated on the following criteria: percentage of fertile females,

TABLE 3

Test of food choice and daily prey consumption by A. nemorum females.

Test de choix de nourriture et consommation journalière de proies par des femelles d'A. nemorum.

\begin{tabular}{|c|c|c|}
\hline $\begin{array}{l}\text { Prey species exposed } \\
\text { as group to predators }\end{array}$ & $\begin{array}{l}\text { Number of individuals } \\
\text { exposed daily }\end{array}$ & $\begin{array}{c}\text { Average number of prey consumed daily } \\
\text { per } A \text {. nemorum female } \\
\text { (14 individuals tested) }\end{array}$ \\
\hline Psylla pyri & 5 & $2.1 \pm 0.6$ \\
\hline Trioza urticae & 10 & $5.8 \pm 1.6$ \\
\hline Schizaphis graminum & 5 & $2.2 \pm 0.5$ \\
\hline Metopolophium dirhodum & 5 & $2.7 \pm 0.4$ \\
\hline Brevicoryne brassicae $\ldots \ldots \ldots \ldots \ldots \ldots \ldots$ & 5 & $2.9 \pm 0.7$ \\
\hline Myzus persicae & 5 & $3.1 \pm 0.5$ \\
\hline
\end{tabular}

Total number of prey exposed daily to one

A. nemorum female 
TABLE 4

Effect of prey density on predation by A. nemorum females.

Effet de la densité des proies sur la prédation des femelles d'A. nemorum.

\begin{tabular}{|c|c|c|c|c|c|c|}
\hline Prey species & $\begin{array}{l}\text { Number of prey } \\
\text { per } 70 \mathrm{~cm}^{3} \text { cage }\end{array}$ & $\begin{array}{l}\text { Average number } \\
\text { of prey consumed daily } \\
\text { per } A \text {. nemorum female }\end{array}$ & \multicolumn{2}{|c|}{$\begin{array}{c}\text { Comparison of the measures } \\
\text { of voracity }(1)\end{array}$} & & \\
\hline \multirow{3}{*}{ Myzus persicae } & 10 & $6.8 \pm 2$ & \multirow{6}{*}{\multicolumn{2}{|c|}{]$\left.\left.^{*}\right]^{*}\right]^{*}$}} & & \\
\hline & 30 & $13.7 \pm 3.1$ & & & & \\
\hline & 60 & $16.2 \pm 5.5$ & & & & \\
\hline \multirow{3}{*}{ Psylla pyri } & 10 & $5.0 \pm 3$ & & & \multirow{3}{*}{0} & \\
\hline & 30 & $5.8 \pm 1.6$ & & & & \\
\hline & 60 & $9.0 \pm 4.1$ & & & & \\
\hline
\end{tabular}

(1) Level of significance of the differences by variance analysis and test $F$.

0 : No significant difference.

* : Significant difference (threshold $5 \%$ ).

** : Highly significant difference (threshold $1 \%$ ).

TABLE 5

Reproductive capabilities of A. nemorum.

Capacités reproductrices d'A. nemorum.

\begin{tabular}{|c|c|c|c|c|c|c|}
\hline & Lot & 1 & 2 & 3 & 4 & 5 \\
\hline $\begin{array}{c}\text { Prey of } A . \text { nemorum } \\
\text { larvae }\end{array}$ & & $\begin{array}{l}\text { varied } \\
\text { (nature) }\end{array}$ & $\begin{array}{l}\text { M. dirhodum } \\
\text { (lab.) }\end{array}$ & $\begin{array}{l}\text { eggs of } \\
\text { E. kuehniella }\end{array}$ & $\begin{array}{c}\text { T. urticae } \\
\text { M. evansi } \\
\text { Cicadellidae }\end{array}$ & P. pyri \\
\hline $\begin{array}{c}\text { Prey of } A . \text { nemorum } \\
\text { adults }\end{array}$ & & $\begin{array}{l}\text { M. dirhodum } \\
\text { (lab.) }\end{array}$ & $\begin{array}{l}\text { M. dirhodum } \\
\text { (lab.) }\end{array}$ & $\begin{array}{l}\text { eggs of } \\
\text { E. kuehniella }\end{array}$ & $\begin{array}{l}\text { T. urticae } \\
\text { M. evansi } \\
\text { Cicadellidae }\end{array}$ & P. pyri \\
\hline $\begin{array}{l}\text { Average weight of un- } \\
\text { fed adults (mg) }\end{array}$ & $\begin{array}{l}\circ \\
\wp\end{array}$ & & $\begin{array}{l}1.3 \\
1.8\end{array}$ & $\begin{array}{l}1.3 \\
1.7\end{array}$ & & $\begin{array}{l}1.1 \\
1.5\end{array}$ \\
\hline $\begin{array}{l}\text { Growth Rate Index } \\
\text { (GRI) }\end{array}$ & $\begin{array}{l}q \\
q\end{array}$ & & $\begin{array}{l}4.9 \\
6.9\end{array}$ & $\begin{array}{l}5.3 \\
7\end{array}$ & & $\begin{array}{l}4.7 \\
6.1\end{array}$ \\
\hline $\begin{array}{l}\text { Percentage of fertile } \\
\text { females }\end{array}$ & & 65 & 18.6 & 31 & 47 & 23 \\
\hline $\begin{array}{l}\text { Number of fertile fe- } \\
\text { males tested }\end{array}$ & & 13 & 70 & 12 & 14 & 11 \\
\hline $\begin{array}{l}\text { Average longevity of } \\
\text { females (days) }\end{array}$ & & 42 & 22 & 35.5 & 27.9 & 24 \\
\hline $\begin{array}{l}\text { Average duration of } \\
\text { the egg laying period } \\
\text { (days) }\end{array}$ & & 29.3 & 9 & 17.5 & 17 & 13 \\
\hline $\begin{array}{l}\text { Average fecundity per } \\
\text { female }\end{array}$ & & 146 & 27 & 37.3 & 75 & 52.2 \\
\hline $\begin{array}{l}\text { Average number of } \\
\text { eggs laid daily per } \\
\text { female }\end{array}$ & & 5 & 3 & 2 & 4.4 & 4 \\
\hline
\end{tabular}

longevity of females, duration of egg-laying period, total number of eggs laid and number of eggs laid daily. Five lots were defined (table 5). In the 1st case, $A$. nemorum nymphs developed in the field with various unknown prey. They were collected at the end of the 5th nymphal instar and reared at the laboratory on $M$. dirhodum. Adults resulting from these nymphs were paired and fed on this prey until death. In the 2nd case, $A$. nemorum was fed on $M$. dirhodum from hatching of eggs to death of adults. In the 3rd case, 
A. nemorum was exclusively fed on eggs of $E$. kuehniella. In the 4 th case, $A$. nemorum was fed on various prey collected on nettle : $T$. urticae, $M$. evansi, $E$. urticae and $E$. aurata. In the 5 th case, $A$. nemorum was exclusively fed on $P$. pyri nymphs and adults. In each lot, barley leaves were provided as the egg-laying site.

Results listed in table 5 led us to the following conclusions :

1) The larvae fed in the field gave high-fecundity females. Average number of eggs laid was 146. Maximum number of eggs laid in the laboratory by an individual in our study was 175 comparable to PESKA (1931), 203 ; to HILL (1957), 213 ; to COLLYER (1967), 172. It was 5 times weaker in adults resulting from nymphs fed in the laboratory on $M$. dirhodum.

2) The best prey for rearing larvae in the laboratory were various prey living on nettle. However, fecundity was half the fecundity of individuals which accomplished their nymphal development in the field.

3) $P$. pyri was a prey of moderate value. At the lab, it induced an average fecundity equal to $1 / 3$ the fecundity of individuals collected in the field.

4) E. kuehniella eggs were not favourable to A. nemorum development.

5) Nutritional value of $M$. dirhodum was very weak.

6) Nymphal development was revealed as the critical period during which the quality of food conditioned adults for reproductive performance.

It is notable that differences observed in fecundity of the various lots were not related to weight of adults, nor to nymphal development rate. For example, nymphs fed on $P$. pyri gave adults lighter than those from nymphs fed on $M$. dirhodum. However, fecondity of the 1st was almost twice that of the 2 nd. Therefore, it is probable that quality of fat body used during ovarian maturation was more important than quantity and that this quality was directly related to quality of food consumed.

In conclusion, we can say that, although $A$. nemorum is a very polyphagous species, and not discriminating in the choice of its prey in the laboratory, differences in nutritional value of prey induce important differences in the reproductive performance of the predator. Our data clearly indicate that $P$. pyri does not belong to high nutritional value prey for $A$. nemorum. Herbaceous strata bearing varied prey species would thus be advantageous to $A$. nemorum when compared to the limited orchard environment.

\section{F. Choice of egg laying site}

A. nemorum inserts its eggs under the foliar epidermis of host plants of its prey. Presence of favourable egg laying sites is one of the essential conditions of establishment of a population in habitat, so we tested the value as an egg-laying site for $A$. nemorum, of young leaves of pear tree and barley, in the presence or absence of prey. Another objective was also to know if barley leaves could be considered a favourable egg laying site in rearing of the predator in the laboratory. The 1 st choice was barley infested with $M$. dirhodum or pear leaves infested with $P$. pyri. The 2 nd choice was pear without psylla or
TABLE 6

Choice of egg laying site by A. nemorum in relation to host plant and presence of prey.

Choix du site de ponte chez. A. nemorum en fonction de la plante hôte et de la présence de proies.

\begin{tabular}{|c|c|c|c|}
\hline & Egg laying site & $\begin{array}{l}\text { Percentage of eggs } 1 \\
\text { pear }\end{array}$ & $\begin{array}{l}\text { laid on } \\
\text { barley }\end{array}$ \\
\hline 1st choice & $\begin{array}{l}\text { - pear } \\
\text { - barley }+M . \text { dirhodum }\end{array}$ & 35 & 65 \\
\hline 2nd choice & $\begin{array}{l}\text { - pear }+P . \text { pyri } \\
\text { - barley }+M . \text { dirhodum }\end{array}$ & 29 & 71 \\
\hline 3rd choice & $\begin{array}{l}- \text { pear }+P \cdot \text { pyri } \\
- \text { barley }\end{array}$ & 52 & 48 \\
\hline
\end{tabular}

barley with aphids. The 3rd choice was pear with psylla or barley without aphids. Twenty female $A$. nemorum were tested.

The results noted in table 6 show that when the 2 host-plants were infested, barley was clearly preferred as an egg laying site. When only barley was infested, it was very clearly preferred to pear leaves. The percentages of eggs laid on pear leaves was about the same in the presence or absence of prey. When only pear leaves were infested, the same percentage of eggs was laid on both host plants. This shows that the presence of prey stimulated the egg-laying of A. nemorum, and pear leaves were not a very favourable egg-laying site for the predator. It was not more attracted by pear with prey than it was by barley leaves without prey.

The weak attraction of pear leaves as an egg-laying site helps explain why $A$. nemorum does not regularly frequent this habitat in high numbers.

\section{CONCLUSION AND DISCUSSION}

Thus, it was shown that in the Paris region A. nemorum is much less abundant in summer on pear trees than in the herbaceous stratum (especially nettles) close to orchards. A. nemorum prefers a habitat where prey are not only abundant but varied. Although it is a very voracious predator, capable of predatory reflex against the 1st prey encountered, all prey do not have the same nutritive value, and their quality heavily influences the reproductive capability of the predator. The variety of prey species occurring on nettle is especially favourable to proliferation of $A$. nemorum. On the other hand, $P$. pyri is of rather weak value as prey, and pear leaves of poor value as an egg-laying site for $A$. nemorum. Interestingly only very few individuals were found in autumn and winter in traps placed in the nettles. Third generation adult abundance in autumn on pear trees, is directly tied to the feeding or prehibernating adults and to their search for a hibernation site, as evidenced by the trap catches in pear trees.

$A$. nemorum, thus, is an occasional predator of $P$. pyri, and its impact against this pest is quite limited. Its position in the biological complex of the pear psylla cannot be considered as equivalent to that 
of $A$. nemoralis, this latter species being very closely tied to $P$. pyri and one of its most efficacious enemies.

It seems to us, that for reasons here indicated, $A$. nemorum cannot be considered as a potentially efficient biological control agent against the pear psylla, in its original area or in a potential area of introduction.

Moreover, according to PARKER (1975), variability with latitude of voltinism and of ovarian pause in A. nemorum, is genetically determined. In case A. nemorum were to be exported and released in another country, it is probable that specimens belonging to distinct geographical races from Europe, could be used only in areas where climatic conditions are close to those of their original habitat. Results from introduction of $A$. nemorum specimens from the Paris region, to combat $P$. pyricola in the Yakima Valley (Washington, USA) are not yet known but will be interesting to follow to see if they support these conclusions.
The study presented here indicates that only local presence of a species well known as a predator, even in high numbers, does not necessarily mean that its impact on the pest is important. Consequently, it seems to us, that selection of a particular beneficial insect from among many for biological control can only be accurate and useful when the main characteristics of biology, ethology and ecology are known.

Recu le 24 avril 1985 Accepté le 18 juin 1985.

\section{ACKNOWLEDGEMENTS}

We very warmly thank R. C. HEdLund (OICD, Washington, D.C.), who made judicious remarks on the French original version of the manuscript, R. RIEUX (I.N.R.A., Montfavet), G. FAUvel (I.N.R.A., Montpellier) and P. ATGER (I.N.R.A., St-Marcel-lesValence) and B. D. Perkins (EPL, USDA, Behoust) who reviewed the manuscript.

\section{REFERENCES}

Anderson N. H., 1962a. Growth and fecundity of Anthocoris spp. reared on various prey (Het. : Anthocoridae). Entomol. exp. appl., $5,40-52$

Anderson N. H., 1962b. Studies on overwintering of Anthocoris (Hem. : Anthocoridae). Entomol. Mon. Mag., 98, 1-3.

Anderson N. H., 1962c. Bionomics of six species of Anthocoris (Het. : Anthocoridae) in England. Trans. R. entomol. Soc. Lond. 114 (3), 67-95.

Bonnemaison L., Missonnier J., 1956. Le psylle du poirier (Psylla pyri L.). Morphologie et biologie. Méthodes de lutte. $A n n$. Epiphyt., 7, (2), 263-331.

Bouyjou B., Canard M., Nguyen T. X., 1984. Analyse par frappage des principaux prédateurs et proies potentielles en verger de poiriers non traité, p. 148-166. Coll. int. sur la lutte intégrée contre les psylles du poirier, Toulouse, 27-29 Sept. 1983, Bull. OILB/SROP, VII (5), $388 \mathrm{p}$.

Bronnimann H., 1964. Rearing anthocorids on an artificial medium. Tech. Bull. Commonw. Inst. Biol. Contr., 4, 147-150.

Carl K., Zwölfer H., 1965. Untersuchungen zur biologischen Bekämpfung einiger unkräuter und Schädlinge in Landwirtschaf und Obstbau. 2. Berich über die Arbeiten der europäischen Station des Commonwealth Institute of biological control, Delémont, Schweiz. 1. Teil. Anz. Schädlingsk., 38 (6), 81-87.

Clausen C. P., 1978. Introduced parasites and predators of Arthropod pests and weeds. Pear psylla, Psylla pyricola Foerster, p. 170. In : USDA Agr. Handb. 480, Washington D.C., 545 p.

Collyer E., 1967. On the ecology of Anthocoris nemorum (L.) (Hem. : Heteroptera). Proc. R. Entomol. Soc. Lond., (A), 42 (7-9), 107-118.

Fields C. J., Beirne B. P., 1973. Ecology of Anthocorid predators of the pear psylla in the Okanagan Valley, British Columbia. $J$. Entomol. Soc. Br. Columbia, 70 (1), 18-19.

Georgala M. B., 1957. A contribution to the biology of the pear sucker. Psylla pyricola. 44th Rep. E. Malling Res. Stn. 1955-56, 135-141.

Hérard F., 1985. Analysis of parasite and predator populations observed in pear orchards infested by Psylla pyri (L.) (Hom. . Psyllidae) in France. Agronomie, 5 (9).

Hérard F., 1986. Annotated list of the entomophagous complex associated with pear psylla, Psylla pyri (L.) (Hom. : Psyllidae) in France. Agronomie, 6 (1).

Hill A. R., 1957. The biology of Anthocoris nemorum in Scotland (Hem. : Anthocoridae). Trans. R. entomol. Soc. Lond., 109 (13), 379-394.

Lauenstein G., 1976. Untersuchungen zu Biologie und Verhaltensweisen der räuberischen Blumenwanze Anthocoris nemorum L. (Het. : Anthocoridae). Diss. Univ., Göttingen.

Lauenstein G., 1977. Untersuchungen zu Fruchtbarkeit und Eiablage der räuberischen Blumenwanze Anthocoris nemorum L. (Hem. : Heteroptera). Z. angew. Entomol., 83 (4), 355-363.

Lauenstein G., 1980a. Zum Suchverhalten von Anthocoris nemorum L. (Het. : Anthocoridae). Z. angew. Entomol., 89 (5), 428-442.

Lauenstein G., 1980b. Zur Aufnahme von Pflanzensubstanz durch die räuberische Blumemwanze Anthocoris nemorum L. (Hem. : Heteroptera). Entomophaga, 24 (4), 431-441.

Mc Mullen R. D., Jong C., 1967. New records and discussion of predators of the pear psylla, Psylla pyricola Foerster, in British Columbia. J. Entomol. Soc. Br. Columbia, 64, 35-40.

Nguyen T. X., Delvare G., 1984. Bioconose des psylles du poirier et leur complexe parasitaire. Déf. Vég., 209, 221-226.

Nguyen T. X., Delvare G., 1984. Biocoenose des psylles du poirier (Psylla pyri L. et Psylla pyrisuga Foerster) dans la région toulousaine, France, p. 191-197. In : Coll. int. sur la lutte intégrée contre les psylles du poirier, Toulouse, 27-29 Sept. 1983, Bull. OILB/SROP, VII (5), $388 \mathrm{p}$

Parker N. J. B., 1975. An investigation of reproductive diapause in two British populations of Anthocoris nemorum (Hem.: Anthocoridae). J. Entomol. (A), 49 (2), 173-178.

Peska W., 1931. Obserwacje nad biologja dziobalka gajowego (Anthocoris nemorum L.). Trans. Dep. Plant Dis. St. Inst. Agric. Bydgoszcz (Bromberg), 10, 53-71.

Scheurer R., Ruzette M. A., Fluck V., 1975. Effects of treatment with an insect growth regulator on the pear psylla (Psylla pyri $\mathrm{L}$.) under field conditions. Z. angew. Entomol., 78 (3), 313-316.

Wojnarowska P., Baranowna I., Lipowa I., 1960. Psylla pyri L. miodowka gruszowa planista szkodnik grusz. Prace nauk. Inst. Ochr. Rosl., 2 (1), 143-161. 